\title{
Analisis faktor-faktor yang mempengaruhi ekspor CPO Provinsi Jambi ke Malaysia
}

\author{
Usman Hardianto*; Siti Hodijah; Rahma Nurjannah \\ Prodi Ekonomi Pembangunan, Fak. Ekonomi dan Bisnis, Universitas Jambi \\ *E-mail korespondensi: Usman.hardianto.8@gmail.com
}

\begin{abstract}
The purpose of the study was to determine and analyze the development of production, exchange rates, CPO prices, Malaysian GDP, and Jambi Province CPO exports to Malaysia and the effect of production, exchange rates, CPO prices, Malaysian GDP on Jambi Province CPO exports to Malaysia. The data used in this study is secondary data in the form of time series data for 2000-2017. The results show that the average development of Jambi Province CPO exports to Malaysia is $4.10 \%$ per year, Jambi Province CPO production is on average 4, 10\% per year, the average exchange rate is $2.64 \%$ per year, the average CPO price is $8.63 \%$ per year, and Malaysia's GDP is $4.89 \%$ per year on average. Based on the results of multiple linear analyses, it can be concluded that CPO production, CPO prices, exchange rates, and Malaysian GDP together affect the volume of Jambi Province's CPO exports to Malaysia. While partially production and GDP have a negative and insignificant effect on Jambi Province's CPO exports to Malaysia, the exchange rate and CPO prices positively and significantly impact Jambi Province's CPO exports to Malaysia.
\end{abstract}

Keywords: Production, Price, Exchange rates, Gross Domestic Product

\begin{abstract}
Abstrak
Tujuan penelitian adalah Untuk mengetahui dan menganalisis perkembangan produksi, nilai tukar, harga CPO, GDP Malaysia dan ekspor CPO Provinsi Jambi ke Malaysia serta pengaruh produksi, nilai tukar, harga CPO, GDP Malaysia terhadap ekspor CPO Provinsi Jambi ke Malaysia. Data yang digunakan dalam penelitian ini adalah data sekunder berupa data deret waktu untuk periode 2000-2017.Hasil penelitian menunjukkan bahwa rata-rata perkembangan ekspor CPO Provinsi Jambi ke Malaysia sebesar 4,10\% pertahun, produksi CPO Provinsi Jambi rata-rata sebesar 4,10\% pertahun, nilai tukar rata-rata sebesar $2,64 \%$ pertahun, harga CPO rata-rata sebesar 8,63\% pertahun dan GDP Malaysia rata-rata sebesar 4,89\% pertahun. Berdasarkan hasil analisis linier berganda, dapat disimpulkan bahwa produksi $\mathrm{CPO}$, harga $\mathrm{CPO}$, nilai tukar dan GDP Malaysia secara bersama-sama mempengaruhi volume ekspor CPO Provinsi Jambi ke Malaysia. Sementara secara parsial produksi dan GDP berpengaruh negative dan tidak signifikan terhadap ekspor CPO Provinsi Jambi ke Malaysia, sedangkan nilai tukar dan harga CPO berpengaruh positif dan signifikan terhadap ekspor CPO Provinsi Jambi ke Malaysia.
\end{abstract}

Kata kunci : Produksi, Harga, Nilai tukar, Produk Dometik Bruto.

\section{PENDAHULUAN}

Perdagangan internasional merupakan perdagangan yang terjadi antar lintas Negara dan memiliki peran penting dalam meningkatkan pertumbuhan ekonomi disuatu 
Negara yang melakukan perdagangan internasional. Salah satu penyebab perdagangan internasional adalah karena perbedaan sumberdaya alam yang dimiliki, perbedaan kondisi geografis, iklim, teknologi, struktur ekonomi, kualitas tenaga kerja, sosial dan politik. Adanya perbedaan tersebut, maka masing-masing Negara akan memproduksi barang yang berbeda sehingga masing-masing Negara akan memenuhi kebutuhannya.

Menrurut Sukirno (2010) ekspor merupakan penjualan barang keluar negeri dengan menggunakan system pembayaran, kualitas, kuantitas dan syart penjualan lainya yang telah disetujui oleh pihak dari importer. Permintaan ekspor adalah permintaan jumlah barang atau jasa yang diminta untuk diekspor dari suatu Negara kenegara lain.

Indonesia merupakan salah satu Negara berkembang yang memiliki potensi sumber daya alam yang sangat beragam. Salah satu potensi sumber daya alam yang cukup besar adalah sektor pertanian dan perkebunan. Selain itu, Indonesia juga memiliki lahan perkebunan yang sangat subur yang dapat ditanami dengan berbagai jenis tanaman perkebunan seperti cengkeh, kopi, karet, teh, kelapa sawit dan tanaman perkebunan lainnya.

Salah satu tanaman perkebunan yang menjadi andalan ekspor di Indonesia adalah tanaman kelapa sawit. Hal ini dikarenakan kelapa sawit merupakan salah satu komoditi ekspor di Indonesia yang memiliki nilai yang cukup penting sebagai sumber devisa Negara. Pada tahun 2017 jumlah produksi kelapa sawit di Indonesia mencapai 35.359.384 ton. Hal ini yang membuat Indonesia menjadi Negara produsen kelapa sawit terbesar setelah Malaysia. Selain itu, Indonesia juga telah melakukan ekspor kelapa sawit sebanyak 1.325.147 ton pada tahun 2017.

Salah satu Provinsi yang memiliki potensi besar terhadap tanaman kelapa sawit adalah Provinsi Jambi. Saat ini, ekspor CPO merupakan sumber devisa terbesar bagi Provinsi Jambi selain karet. Negara tujuan ekspor CPO Provinsi Jambi terbesar adalah India, China dan Malaysia. Pada tahun 2017 volume ekspor CPO Provinsi Jambi ke Malaysia cukup tinggi. Hal ini terjadi karena adanya kegiatan kerjasama antara Negara Indonesia dengan Malaysia dalam bidang industri minyak kelapa sawit.

Pada tahun 2013 volume ekspor CPO Provinsi Jambi ke Malaysia mengalami peningkatan mencapai 89,455 ton dan kembali menurun pada tahun 2014 menjadi 78.000 ton dan tahun 2015 menjadi 43.300 ton. Akan tetapi pada tahun 2016 volume ekspor CPO Provinsi Jambi ke Malaysia mengalami peningkatan sebesar 97.854 ton dan tahun 2017 mencapai 98.301 ton.

Pada tahun 2017 volume ekspor CPO Provinsi Jambi ke Malaysia cukup tinggi. Hal ini terjadi karena adanya kegiatan kerjasama antara Negara Indonesia dengan Malaysia dalam bidang industri minyak kelapa sawit. Manfaat dari kegiatan kerjasama antara Indonesia dengan Malaysia dalam bidang tersebut untuk memberikan peningkatan daya saing ekspor CPO di pasar global sehingga CPO Indonesia dapat diterima secara luas. Alasan lainnya adalah karena adanya pertumbuhan industriindustri yang ada di Malaysia yang membutuhkan bahan baku CPO. Hal ini menunjukan ketergantungan industri hilir malaysia dengan pasokan bahan baku CPO dari indonesia. Seiring dengan kebergantungan dunia terhadap CPO yang semakin tinggi, volume permintaan ekspor $\mathrm{CPO}$ indonesia ke dunia terus mengalami peningkatan (Gunawan, 2018).

Volume ekspor CPO dari Provinsi Jambi ke Negara Malaysia tersebut tentu dipengaruhi oleh beberapa faktor seperti produksi CPO, nilai tukar, harga CPO dan GDP (Gross Domestic Product) Negara tujuan ekspor. 
Berdasarkan latar belakang tersebut, maka peneliti tertarik untuk melakukan penelitian yang berjudul "Analisis Faktor-Faktor Yang Mempengaruhi Ekspor CPO Provinsi Jambi Ke Malaysia".

\section{METODE}

Jenis data yang digunakan dalam penelitian ini adalah Data Sekunder,berupa data time series yang berasal dari Badan Pusat Statistik Provinsi Jambi. Metode analisis yang digunakan yaitu analisis deskriptif dan regresi linear berganda.

Menganalisis perkembangan produksi, nilai tukar, harga CPO, GDP Malaysia dan ekspor CPO Provinsi Jambi ke Malaysia digunakan rumus perkembangan sebagai berikut:

Keterangan

$$
\mathrm{CPO}=\frac{\mathrm{P} t-\mathrm{Pt}_{-1}}{\mathrm{Pt}_{-1}} \times 100 \%
$$

$\mathrm{P}=$ Perkembangan

$\mathrm{P}_{\mathrm{t}}=$ perkembangan pada tahun $(\mathrm{t})$

$\mathrm{P}_{\mathrm{t}-1}=$ perkembangan pada tahun sebelumnya.

Menganalisis faktor-faktor yang mempengaruhi ekspor CPO Provinsi Jambi ke Malaysia,digunakan model regresi dengan persamaan sebagai berikut :

Keterangan:

$$
Y=\beta_{0}+\beta_{1_{\text {prod }}}+\beta_{2_{\text {harga }}}+\beta_{3_{\text {kurs }}}+\beta_{4 \text { GDP }}+e
$$

$$
\begin{array}{ll}
\mathrm{Y} & =\text { Ekspor CPO } \\
\beta_{0} & =\text { konstanta } \\
\beta_{1_{\mathrm{m}} 4} & =\text { Koefisisen regresi } \\
\text { Prod } & =\text { produksi CPO } \\
\text { Harga } & =\text { Harga CPO } \\
\text { Kurs } & =\text { Nilai tukar } \\
\text { GDP } & =\text { GDP Malaysia } \\
e & =\text { Standart eror }
\end{array}
$$

\section{HASIL DAN PEMBAHASAN}

\section{Volume ekspor CPO Provinsi Jambi ke Malaysia}

Provinsi Jambi merupakan salah satu wilayah di Indonesia yang memiliki potensi tanaman kelapa sawit yang cukup baik. Dalam usahanya, Provinsi Jambi juga melakukan ekspor CPO kebeberapa Negara tujuan seperti Malaysia dengan tujuan untuk memperoleh pendapatan.

Pada dasarnya kegiatan ekspor CPO yang dilakukan oleh Provinsi Jambi memiliki beberapa keuntungan. Salah satu keuntungan tersebut dapat dijadikan sebagai sumber devisa bagi Provinsi Jambi yang nantinya dapat digunakan untuk pembangunan ekonomi di Provinsi Jambi. hal ini sesuai dengan pendapat Tina (2013) bahwa kegiatan ekspor menimbulkan beberapa manfaat seperti mendukung Negara untuk meningkatkan pendapatan devisa, membuka lapangan pekerjaan dan memperluas jangkauan wilayah perdagangan terutama pemasaran hingga kedunia internasional.

Berdasarkan Tabel 1 menunjukkan bahwa volume ekspor CPO Provinsi Jambi ke Malaysia pada tahun 2000 sampai 2017 berada pada kondisi yang berfluktuasi. Volume ekspor yang berfluktuasi tersebut berakibat kepada perkembangan volume ekspor yang berfluktuasi pula. Selama tahun 2000 sampai tahun 2017 perkembangan volume ekspor 
CPO Provinsi Jambi ke Malaysia rata-rata sebesar 30,13\%. Perkembangan tertinggi terjadi pada tahun 2015 sebesar 59,71\%. Hal ini diduga karena pada tahun 2015 volume ekspor CPO meningkat dibanding tahun sebelumnya sehingga berakibat pada perkembangan yang meningkat pula. Selanjutnya perkembangan terendah terjadi pada tahun 2012 sebesar $-72,95 \%$.

Ada beberapa faktor yang menyebabkan naik dan turunnya volume ekspor CPO Provinsi Jambi ke Malaysia. Faktor-faktor tersebut antara lain produksi CPO itu sendiri, harga CPO dunia dan GDP dari Negara importer. Menurut Khairan (2017) adapun faktor-faktor yang dapat mempengaruhi permintaan ekspor terhadap suatu komoditas seperti harga ekspor, faktor pendapatan dan selera konsumen.

Tabel 1.Volume ekspor CPO Provinsi Jambi ke Malaysia Tahun 2000-2017

\begin{tabular}{ccc}
\hline Tahun & Volume Ekspor (ton) & Perkembangan (\%) \\
\hline 2000 & 12.328 & - \\
2001 & 28.831 & 13,87 \\
2002 & 20.332 & $-29,48$ \\
2003 & 13.810 & $-32,08$ \\
2004 & 35.105 & 15,20 \\
2005 & 53.853 & 53,41 \\
2006 & 83.594 & 55,23 \\
2007 & 37.900 & $-54,66$ \\
2008 & 46.398 & 22,42 \\
2009 & 47.092 & 1,50 \\
2010 & 105.100 & 12,18 \\
2011 & 89.455 & $-14,89$ \\
2012 & 24.200 & $-72,95$ \\
2013 & 37.800 & 56,20 \\
2014 & 43.300 & 14,55 \\
2015 & 69.154 & 59,71 \\
2016 & 97.854 & 41,50 \\
2017 & 98.301 & 0,46 \\
\hline
\end{tabular}

Sumber :Statistik Provinsi Jambi (2000-2017), (diolah)

\section{Perkembangan produksi CPO Provinsi Jambi}

Adapun produksi CPO Provinsi Jambi 2013 produksi CPO di Provinsi Jambi mengalami peningkatan sebesar 1.555 .697 ton dengan laju p perkembangan sebesar $106,36 \%$ dan kembali menurun menjadi 977.799 ton dengan perkembangan sebesar $37,15 \%$ pada tahun 2014.

Selanjutnya tahun 2015 produksi CPO di Provinsi Jambi kembali meningkat menjadi 1.013.811 ton dengan laju perkembangan sebesar 3,68\%. Sedangkan pada tahun 2016 produksi CPO di Provinsi Jambi sebesar 1.552.543 ton dengan laju perkembangan 53,14\%. Kondisi ini tidak bertahan lama karena pada tahun 2017 produksi CPO di Provinsi Jambi kembali mengalami penurunan sebesar 108.080 ton dengan perkembangan sebesar $-93,04 \%$. Selama tahun 2000 sampai 2017 dapat dilihat pada Tabel 2.

Berdasarkan Tabel 2 menjelaskan bahwa produksi CPO di Provinsi Jambi juga mengalami hal yang sama dengan volume ekspor CPO Provinsi Jambi ke Malaysia, 
yaitu sama-sama mengalami fluktuasi. Rata-rata perkembangan produksi CPO Provinsi Jambi ke Malaysia pada tahun 2000 sampai 2017 sebesar 4,10\%. Perkembangan produksi CPO tertinggi terjadi pada tahun 2013 mencapai angka 106,36\%. Hal ini terjadi diduga karena adanya perluasan lahan serta peningkatan produksi buah segar kelapa sawit yang berakibat pada peningkatan jumlah produksi CPO. Perkembangan terendah terjadi pada tahun 2017 sebesar $-93,04 \%$.

Produksi CPO di Provinsi Jambi yang tidak stabil tentunya tidak lepas dari pengaruh berbagai faktor, diantaranya adalah kondisi TBS yang tidak stabil, adanya perubahan struktur lahan kelapa sawit serta beberapa faktor yang dapat mempengaruhi produksi CPO termasuk didalamnya faktor teknis dalam pengolahannya. Hal ini sesuai dengan pendapat Lumbantoruan, dkk (2013) bahwa dalam melakukan proses produksi $\mathrm{CPO}$, maka perusahaan memerlukan perencanaan yang baik agar pabrik dapat beroperasi secara efisien dan efektif.

Tabel 2.Produksi CPO Provinsi Jambi Tahun 2000-2017

\begin{tabular}{lcc}
\hline Tahun & Produksi CPO (ton) & Perkembangan (\%) \\
\hline 2000 & 640.240 & - \\
2001 & 649.489 & 1,44 \\
2002 & 760.320 & 17,06 \\
2003 & 664.164 & $-12,65$ \\
2004 & 795.848 & 19,83 \\
2005 & 936.595 & 17,69 \\
2006 & 1.009 .448 & 7,78 \\
2007 & 1.035 .300 & 2,56 \\
2008 & 1.203 .545 & 16,25 \\
2009 & 1.237 .924 & 2,86 \\
2010 & 1.266 .225 & 2,29 \\
2011 & 1.326 .081 & 4,73 \\
2012 & 753.859 & $-43,15$ \\
2013 & 1.555 .697 & 106,36 \\
2014 & 977.799 & $-37,15$ \\
2015 & 1.013 .811 & 3,68 \\
2016 & 1.552 .543 & 53,14 \\
2017 & 108.080 & $-93,04$ \\
\hline
\end{tabular}

Sumber : Statistik Provinsi Jambi (2000-2017),(diolah)

Produksi kelapa sawit yang terus meningkat setiap tahun memberikan manfaat antara lain meningkatkan pendapatan petani dan masyarakat, produksi yang menjadi bahan baku industry pengolahan yang menciptakan nilai tambah didalam negeri, ekspor minyak kelapa sawit yang menghasilkan devisa dan menyediakan lapangan kerja (Sukandar, 2012).

\section{Perkembangan nilai tukar}

Menurut Mankiw (2010) perubahan nilai tukar ada dua yaitu apresiasi dan depresiasi. Apresiasi adalah suatu kondisi dimana terjadi peningkatan mata uang yang dihitung oleh jumlah uang asing yang dibeli. Sedangkan depresiasi adalah suatu kondisi dimana terjadi penurunan terhadap nilai mata uang asing yang dihitung oleh jumlah mata uang yang dapat dibelinya. 
Adapun nilai mata uang Negara Indonesia pada tahun 2013 nilai tukar rupiah sebesar 9.622 rupiah per dollar Amerika Serikat dengan perkembangan sebesar 2,58\%. Tahun 2014 nilai tukar rupiah menjadi 12.440 rupiah per dollar Amerika Serikat dengan perkembangan sebesar 29,29\%. Sedangkan pada tahun 2015 sampai 2017 nilai tukar rupiah terus tinggi dimana pada tahun 2015 nilai tukar rupiah sebesar 13.759 rupiah per dollar Amerika Serikat dengan perkembangan 10,60\%. Tahun 2016 nilai tukar rupiah menjadi 13.744 rupiah per dollar Amerika Serikat dengan perkembangan -0,11\% dan tahun 2017 menjadi 13.568 rupiah per dollar Amerika Serikat dengan perkembangan 1,28\%.Pada tahun 2000 sampai tahun 2017 dapat dilihat pada Tabel 3. sebagai berikut.

Tabel 3. Nilai tukar rupiah Tahun 2000-2017

\begin{tabular}{ccc}
\hline Tahun & Nilai Tukar (Rupiah) & Perkembangan (\%) \\
\hline 2000 & 9,595 & - \\
2001 & 10,266 & 6.99 \\
2002 & 9,261 & -9.79 \\
2003 & 8,571 & -7.45 \\
2004 & 9,030 & 5.36 \\
2005 & 9,751 & 7.98 \\
2006 & 9,141 & -6.26 \\
2007 & 9,142 & 0.01 \\
2008 & 9,772 & 6.89 \\
2009 & 10,356 & 5.98 \\
2010 & 9,078 & -12.34 \\
2011 & 9,068 & -0.11 \\
2012 & 9,380 & 3.44 \\
2013 & 9,622 & 2.58 \\
2014 & 12,440 & 29.29 \\
2015 & 13,759 & 10.60 \\
2016 & 13,744 & -0.11 \\
2017 & 13,568 & -1.28 \\
\hline
\end{tabular}

Sumber : Statistik Ekonomi dan Keuangan Indonesia, (2000-2017), (diolah)

Berdasarkan Tabel 3 nilai tukar rupiah dari tahun 2000 sampai tahun 2017 berfluktuasi. Selama tahun 2000 sampai tahun 2017 rata-rata perkembangan nilai tukar rupiah sebesar 2,46\%. Perkembangan tertinggi terjadi pada tahun 2014 sebesar 29,29\% dikarenakan pada tahun tersebut nilai tukar rupiah melonjak lebih tinggi dibanding dengan tahun-tahun sebelumnya. Kemudian perkembangan nilai tukar rupiah terendah terjadi pada tahun 2010 sebesar -12,34\% dikarenakan nilai mata uang rupiah pada tahun tersebut menurun. Kondisi ini terjadi diduga karena adanya peningkatan suku bungan SBI sehingga berakibat pada perkembngan uang beredar menjadi lambat. Menurut Krugman (2014) ada beberapa faktor utama yang mempengaruhi tinggi rendahnya nilai tukar mata uang dalam negeri terhadap matang uang asing, diantaranya adalah laju inflasi relative, tingkat pendapatan relative dan suku bunga relative.

\section{Perkembangan harga CPO}

Harga CPO dunia setiap tahunnya juga berfluktuasi. Rata-rata perkembangan harga CPO selama tahun 2000 sampai 2017 sebesar 8,63\% dengan perkembangan 
tertinggi terjadipada tahun 2016 sebesar 55,12\% danperkembangan terendah terjadi pada tahun 2017 sebesar $-37,69 \%$. Kondisi ini terjadi diduga karena adanya kebijakan penetapan harga secara internasional sehingga berakibat pula terhadap naik turunnya harga CPO di Provinsi Jambi.Naik dan turunnya harga CPO dunia tentunya dipengaruhi oleh beberapa hal.Menurut Kotler dan Keller (2009) juga menyatakan bahwa faktorfaktor yang menentukan kebijakan penetapan harga adalah memilih tujuan pendapatan harga, menentukan permintaan, memperkirakan biaya, menganalisa biaya, harga dan tawaran pesaing, memilih metode penetapan harga dan memilih harga akhir.Adapun harga CPO dalam penelitian ini dapat dilihat pada Tabel 4.sebagai berikut.

Tabel 4.Harga CPO internasional Tahun 2000-2017

\begin{tabular}{ccc}
\hline Tahun & Harga CPO (Juta Dollar) & Perkembangan (\%) \\
\hline 2000 & 250 & - \\
2001 & 350 & 40.00 \\
2002 & 390 & 11.43 \\
2003 & 395 & 1.28 \\
2004 & 532 & 34.68 \\
2005 & 632 & 18.80 \\
2006 & 412 & -34.81 \\
2007 & 638 & 54.85 \\
2008 & 853 & 33.70 \\
2009 & 792 & -7.15 \\
2010 & 1105 & 039.52 \\
2011 & 1053 & -4.71 \\
2012 & 796 & -11.30 \\
2013 & 894 & 15.21 \\
2014 & 793 & -11.30 \\
2015 & 508 & -35.94 \\
2016 & 788 & 55.12 \\
2017 & 491 & -37.69 \\
\hline & & $\mathbf{8 . 5 7}$ \\
\hline
\end{tabular}

Sumber : Statistik Kementrian Perdagangan Republik Indonesia (2000-2017), (diolah)

Berdasarkan Tabel 4 pada tahun 2013 menjadi 894 juta dollar per ton dengan laju perkembangan sebesar 15,21\%.Tahun 2014 harga CPO sebesar 793 juta dollar per ton dengan perkembangan sebesar -11,30\%. Harga ini kembali menurun di tahun 2015 menjadi 508 juta dollar per ton dengan perkembangan sebesar $-35,94 \%$. Akan tetapi pada tahun 2016 harga CPO kembali meningkat menjadi 788 juta dollar per ton denan perkembangan sebesar 55,12\% dan tahun 2017 kembali menurun menjadi 491 juta dollar per ton dengan perkembangan sebesar $-37,69 \%$.

\section{Gross Domestic Product (GDP) Malaysia}

GDP dapat mencerminkan kinerja ekonomi, sehingga semakin tinggi GDP sebuah Negara dapat dikatakan semakin bagus pula kinerja ekonomi di Negara tersebut. GDP 
Malaysia setiap tahunnya meningkat tetapi perkembangannya berfluktuasi. Hal ini dikarenakan peningkatan GDP Malaysia hanya sedikit sehingga perkembanagnya cenderung naik maupun turun. Perkembangan GDP tertinggi terjadi pada tahun 2004 sebesar 6,78\% sedangkan perkembngan terendah terjadi pada tahun 2009 sebesar $1,51 \%$. Kondisi ini diduga karena adanya perubahan struktur perekonomian yang terjadi di Malaysia sehingga berakibat pada kondisi GDP yang tidak stabil tersebut.GDP dapat mencerminkan kinerja ekonomi, sehingga semakin tinggi GDP sebuah Negara dapat dikatakan semakin bagus pula kinerja ekonomi di Negara tersebut. berdasarkan teori Keynes bahwa GDP terbentuk dari empat faktor yang secara positif mempengaruhinya, seperti konsumsi, investasi, pengeluaran pemerintah dan ekspor neto (Arifin dan Gina, 2009). Adapun GDP Malaysia pada tahun 2000 sampai tahun 2017 dapat dilihat pada Tabel 5.

Tabel 5.GDP Malaysia Tahun 2000-2017

\begin{tabular}{ccc}
\hline Tahun & GDP (US dollar) & Perkembangan (\%) \\
\hline 2000 & 16.252 .312 .144 & - \\
2001 & 16.336 .446 .353 & 0,52 \\
2002 & 17.217 .142 .265 & 5,39 \\
2003 & 18.213 .756 .421 & 5,79 \\
2004 & 19.449 .275 .247 & 6,78 \\
2005 & 20.486 .337 .667 & 5,33 \\
2006 & 21.630 .468 .296 & 5,58 \\
2007 & 22.992 .925 .190 & 6,30 \\
2008 & 24.103 .890 .423 & 4,83 \\
2009 & 23.739 .071 .121 & $-1,51$ \\
2010 & 25.501 .660 .923 & 7,42 \\
2011 & 26.851 .696 .623 & 5,29 \\
2012 & 28.321 .411 .940 & 5,47 \\
2013 & 29.650 .740 .430 & 40,69 \\
2014 & 31.431 .756 .954 & 6,01 \\
2015 & 33.032 .131 .880 & 05,09 \\
2016 & 34.427 .234 .300 & 4,22 \\
2017 & 36.457 .390 .332 & 5,90 \\
\hline
\end{tabular}

Sumber : World Development Indicators , 2000-2017, (diolah)

Tahun 2013 GDP Malaysia berada diangka 28.321.411.940 US\$ dengan perkembangan sebesar 5,47\%. Kemudian ditahun 2014 GDP Malaysia sebesar 31.431.756.954dengan perkembangan sebesar 6,01\% dan tahun 2015 GDP Malaysia sebesar 33.032.131.880 US\$ dengan perkembangan sebesar 5,09\% . selanjutnya pada tahun 2016 dan 2017 GDP Malaysia sebesar 34.427.234.300 US\$ dan 36.457.390.332 US\$ dengan masing-masing perkembangan sebesar 4,11\% dan 5,90\%.

\section{Faktor-faktor yang mempengaruhi ekspor CPO Provinsi Jambi ke Malaysia}

Analisis regresi linear berganda yang dilakukan dalam penelitian ini bertujuan untuk mengetahui pengaruh dari produksi CPO, harga CPO, nilai tukar dan GDP Malaysia terhadap volume ekspor CPO Provinsi Jambi ke Malaysia. Analisis kuantitaif dilakukan dengan regresi linear berganda. 
Tabel 6. Hasil analisis regresi linear berganda

\begin{tabular}{lrcrr}
\hline \multicolumn{1}{c}{ Variable } & Coefficient & Std. Error & t-Statistic & Prob. \\
\hline C & 1.526020 & 4.380924 & 0.348333 & 0.7332 \\
Log (Produksi) & 1.079951 & 0.631294 & 1.710695 & 0.1109 \\
Log (Nilai tukar) & 2.239345 & 0.804239 & 2.784427 & 0.0155 \\
Log (Harga) & 0.908345 & 0.314040 & 2.892451 & 0.0126 \\
Log (GDP) & -1.433343 & 0.706068 & -2.030035 & 0.0633 \\
\hline R-squared & 0.629789 & Mean dependent var & 4.639440 \\
Adjusted R-squared & 0.515878 & S.D. dependent var & 0.286533 \\
S.E. of regression & 0.199367 & Akaike info criterion & -0.157210 \\
Sum squared resid & 0.516711 & Schwarz criterion & 0.090115 \\
Log likelihood & 6.414892 & Hannan-Quinn criter. & -0.123107 \\
F-statistic & 5.528786 & Durbin-Watson stat & 1.700465 \\
Prob(F-statistic) & 0.007979 & & \\
\hline
\end{tabular}

Sumber : Data diolah ,2019

Berdasarkan Tabel tersebut, maka persamaan regresi linear berganda dalam penelitian ini sebagai berikut:

$$
Y=1.526020+1.079951_{\text {prod }}+2.239345_{\text {kurs }}+0.908345_{\text {harga }}-1.433343_{\text {GDP }}
$$

Selanjutnya interpretasi hasil terhadap masing-masing variable sebagai berikut:

\section{Koefisien variabel produksi CPO}

Variabel produksi CPO memiliki nilai koefisien regresi sebesar 1,079951 yang artinya setiap kenaikan produksi CPO sebesar $1 \%$ per tahun maka volume ekspor CPO Provinsi Jambi ke Malaysia akan meningkat sebesar 1.079\%.

\section{Koefisien variabel nilai tukar}

Variabel nilai tukar memiliki nilai koefisien regresi sebesar 2,239345 yan g berarti setiap kenaikan nilai tukar sebesar $1 \%$ maka akan meningkatkan volume ekspor CPO sebesar 2,239\%.

\section{Koefisien variabel harga CPO}

Variabel harga CPO memiliki nilai koefisien regresi sebesar 0,908345 yang artinya setiap kenaikan harga CPO sebesar $1 \%$ maka akan meningkatkan volume ekspor sebesar $0.908 \%$.

\section{Koefisien variabel GDP Malaysia}

Variabel GDP memiliki nilai koefisien regresi sebesar -1,433343 yang artinya setiap kenaikan GDP sebesar 1\% maka akan menurunkan volume ekspor sebesar $1.433 \%$.

\section{Pengujian asumsi klasik}

\section{Uji multikolinearitas}

Uji multikolinearitas bertujuan untuk menguji apakah model regresi ditemukan adanya korelasi antara variabel bebas.Uji ini digunakan untuk menghindari kebiasaan dalam proses pengambilan keputusan mengenai pengaruh parsial masing-masing variabel bebas terhadap variabel terikat Untuk mengetahui indikasi gejala 
multikolinearitas dapat diketahui dari nilai Variance Influence Factor (VIF) dengan standar penilaia nnilai VIF kurang dari 10.

Tabel 7. Hasil uji multikolinearitas

\begin{tabular}{cccc}
\hline \hline Variable & $\begin{array}{c}\text { Coefficient } \\
\text { Variance }\end{array}$ & $\begin{array}{c}\text { Uncentered } \\
\text { VIF }\end{array}$ & $\begin{array}{c}\text { Centered } \\
\text { VIF }\end{array}$ \\
\hline \hline C & 19.19250 & 8691.595 & NA \\
Log (Produksi) & 0.398532 & 6377.164 & 1.128082 \\
Log (Nilai tukar) & 0.646800 & 4706.158 & 1.299690 \\
Log (Harga) & 0.098621 & 346.2114 & 1.370531 \\
Log (GDP) & 0.498532 & 24077.96 & 9.987936 \\
\hline \hline
\end{tabular}

Sumber : Data diolah ,2019

Hasil uji multikolinearitas menunjukkan bahwa produksi CPO memiliki nilai VIF sebesar 1,128082, nilai tukar sebesar 1,299690, harga CPO sebesar 1,370531 dan GDP sebesar 9,987936. Sehingga dapat disimpulkan bahwa model regresi yang digunakan dalam penelitian ini tidak mengalami multikolinearitas atau tidak mengandung korelasi antara variabel dependen.

\section{Uji heterokedastisitas}

Uji heteroskedasitas dalam penelitian ini menggunakan uji Glejser dengan nilai probability $\mathrm{F}_{\text {hitung }}>\alpha=5 \%$ maka tidak terindikasi adanya gejala heterokesdasitas. Adapun hasil dari uji Heterokesdastitas sebagai berikut:

Tabel 8. Hasil uji heterokesdasitas

\begin{tabular}{llll}
\hline \hline F-statistic & 0.546020 & Prob. F(4,13) & 0.7051 \\
Obs*R-squared & 2.589122 & Prob. Chi-Square(4) & 0.6288 \\
Scaled explained SS & 2.151874 & Prob. Chi-Square(4) & 0.7078 \\
\hline \hline
\end{tabular}

Sumber : Data diolah, 2019

Hasil dari uji heterokedastisitas menunjukkan bahwa nilai $F_{\text {hitung }}$ sebesar 0,7078 $\left(F_{\text {hitung }}>\alpha=5 \%\right.$ ) sehingga model regresi dalam penelitian ini tidak terindikasi adanya gejala heterokedastisitas dan persamaannya valid untuk digunakan.

\section{Uji autokorelasi}

Uji autokorelasi digunakan dalam penelitian ini karena data dalam penelitian ini merupakan data time series. Nilai probability yang digunakan dalam uji autokorelasi adalahF $F_{\text {hitung }}>\alpha=5 \%$ maka tidak terindikasi adanya gelaja autokorelasi.

Tabel 9. Hasil uji autokorelasi

Breusch-Godfrey Serial Correlation LM Test:

\begin{tabular}{lrll} 
F-statistic & 0.851424 & Prob. F(2,11) & 0.4531 \\
Obs*R-squared & 2.412944 & Prob. Chi-Square(2) & 0.2993 \\
\hline Sumber : Data diolah, 2019 & &
\end{tabular}

Hasil uji autokorelasi menunjukkan bahwa Prob F sebesar 0.4531. Oleh karena itu nilai p-value $0.4531>\alpha=5 \%$ sehingga dapat disimpulkan bahwa model regresi dalam penelitian ini tidak terindikasi adanya gelaja autokorelasi. 


\section{Uji normalitas}

Hasil uji normalitas dalam penelitian ini menunjukkan bahwa nilai $\mathrm{JB}_{\text {hitung }}$ sebesar 4,690297 dengan nilai probability sebesar 0,095833. Dimana nilai probability tersebut lebih besar dari 5\% ( $>>\alpha=5 \%)$ sehingga dapat disimpulkan bahwa residual berdistribusi normal dan asumsi klasik tentang kenormalan telah terpenuhi.

\section{Pengujian hipotesis}

\section{Uji F staistik}

Uji F-statistik digunakan untuk menunjukan apakah semua variabel bebas yang di masukan dalam model mempunyai pengaruh secara bersama-sama terhadap variable dependen. Berdasarkan hasil regresi simultan diperoleh nilai $\mathrm{F}_{\text {hitung }}$ sebesar 5,528786 sedangkan nilai $F_{\text {tabel }}$ sebesar 2,96 pada taraf $\alpha=5 \%$ dengan derajat kebebasan $(\mathrm{df}=\mathrm{n}-\mathrm{k})$ sebesar 12. Dengan demikian $F_{\text {hitung }}>F_{\text {tabel }}$ yaitu 5,528786 $>2,96$ yang artinya produksi $\mathrm{CPO}$, harga CPO, nilai tukar dan GDP Malaysia secara bersama-sama mempengaruhi volume ekspor CPO Provinsi Jambi ke Malaysia.

\section{Uji t statistik}

Uji t digunakan untuk menganalisis hipotesis secara parsial atau secara individu guna mengetahui seberapa besar signifikan atau tidak signifikan pengaruh dari masingmasing variabel. Hasil analisis regresi linear berganda diperoleh nilai probability dari variabel produksi CPO sebesar 0,1109 dengan nilai signifikansi lebih besar dari $\alpha=5 \%$ sehingga $\mathrm{H}_{0}$ diterima. Artinya produksi CPO tidak berpengaruh secara signifikan terhadap volume ekspor CPO Provinsi Jambi ke Malaysia.

Hasil analisis regresi linear berganda diperoleh nilai probability dari variabel nilai tukar sebesar 0,0155 dan signifikan pada taraf $\alpha=5 \%$ sehingga $\mathrm{H}_{0}$ ditolak dan $\mathrm{H}_{\mathrm{a}}$ diterima. Hal ini menunjukkan bahwa secara parsial variabel nilai tukar berpengaruh secara signifikan terhadap volume ekspor CPO Provinsi Jambi ke Malaysia.

Hasil analisis regresi linear berganda diperoleh nilai probability dari variabel harga CPO sebesar 0,0126 dan signifikan pada taraf $\alpha=5 \%$ sehingga $\mathrm{H}_{\mathrm{a}}$ diterima. Artinya harga CPO berpengaruh secara signifikan terhadap volume ekspor CPO Provinsi Jambi ke Malaysia. Hasil analisis regresi linear berganda diperoleh nilai probability dari variabel GDP Malaysia sebesar 0,0633 dan tidak signifikan pada taraf $\alpha=5 \%$ sehingga $\mathrm{H}_{0}$ diterima. Artinya GDP Malaysia tidak berpengaruh secara signifikan terhadap volume ekspor CPO Provinsi Jambi ke Malaysia.

\section{Koefisien determinasi $\left(\mathbf{R}^{2}\right)$}

Hasil perhitungan menunjukkan bahwa nilai koefisien determinasi dalam penelitian ini sebesar 0,629789 atau sebesar 62,97\%. Hal ini menunjukkan bahwa variabel produksi CPO, harga CPO, nilai tukar dan GDP Malaysia mempengaruhi volume ekspor CPO Provinsi Jambi ke Malaysia sebesar 62,97\%. Sedangkan sebesar $37,03 \%$ dipengaruhi oleh faktor lain yang tidak termasuk kedalam penelitian ini.

\section{KESIMPULAN DAN SARAN}

\section{Kesimpulan}

Berdasarkan hasil analisis baik secara deskriptif maupun kuantitatif dengan menggunakan model regresi linear berganda maka dapat disimpulkan bahwa:

Perkembangan produksi CPO Provinsi Jambi rata-rata sebesar 4,10\% pertahun, nilai tukar rata-rata sebesar 2,64\% pertahun, harga CPO rata-rata sebesar 8,63\% 
pertahun, GDP Malaysia rata-rata sebesar 4,89\% pertahun dan volume ekspor CPO Provinsi Jambi ke Malaysia rata-rata sebesar 30,13\% pertahun.

Berdasarkan hasil regresi linear berganda variabel nilai tukar dan harga CPO berpengaruh signifikan terhadap volume ekspor CPO Provinsi Jambi ke Malaysia dengan nilai probability $\alpha=5 \%$.

\section{Saran}

Perlu adanya peningkatan ekspor CPO baik dari segi kuantitas maupun kualitas sehingga Indonesia khususnya Provinsi Jambi dapat menguasai pasar Internasional dalam komoditas kelapa sawit.

Diperlukan kebijakan yang lebih terhadap kegiatan pengembangan komoditi perkebunan terutama kelapa sawit. Hal ini dikarenakan kelapa sawit memiliki potensi yang cukup besar dalam perekonomian disuatu wilayah. Salah satu aspek yang harus diperhatikan adalah dari segi produksi CPO terutama dari segi kualitas sehingga dapat sesuai dengan keinginan dari Negara importer dan memperoleh harga yang lebih mahal.

\section{DAFTAR PUSTAKA}

Arifin, I.H. dan Gina.(2017). Membuka cakrawala ekonomi. Grafindo : Bandung.

Gunawan, S. (2018). Motivasi Indonesia bekerjasama dengan Malaysia dalam membentuk the council of palm oil producing countries (CPOPC) Tahun 2015. JOM FISIP. 5 (2) : 1-15.

Khairan A. (2017). Analisis daya saing dan faktor-faktor yang mempengaruhi ekspor CPO Indonesia ke India dan Belanda. Skripsi. Institute Pertanian Bogor : Bogor

Kotler dan Keller.(2009). Manajemen pemasaran. Erlangga : Jakarta.

Krugman. (2014).Pengaruh nilai tukar terhadap ekspor Indonesia. Bulletin Ilmiah Litbang Perdagangan. 7 (1) 174-192

Lumbantoruan., E.P, dan R. Mariati. 2009. Pengaruh produksi nasional terhadap ekspor CPO di Indonesia. Jurnal Ekonomi Produksi. 6(1) 124-139

M Mustika, H Haryadi, \& S Hodijah. (2015).Pengaruh Ekspor dan Impor Minyak Bumi terhadap Pertumbuhan Ekonomi Indonesia, Jurnal Perspektif Pembiayaan dan Pembangunan Daerah, 2 (3), 107-118

Mankiw, N.G.(2012). Pengantar ekonomi makro.Edisi Ketiga. Salemba Empat :Jakarta.

Noviantoro,B; E Emilia; \& YV Amzar. (2017).Pengaruh harga CPO, harga minyak mentah dunia, harga karet dunia dan kurs terhadap defisit neraca transaksi berjalan Indonesia, Jurnal Paradigma Ekonomika, 12 (1), 31-40

Sukandar, I.(2012). Luas area,produksi dan produktivitas kelapa sawit Indonesia. CV. Sinar Harapan : Jakarta.

Sukirno, S. (2010). Makroekonomi. teori pengantar. Edisi Ketiga. Raja Grasindo Persada : Jakarta.

Tina, J. (2013). Ekonomi Internasional. BFFE : Yogyakarta. 